\title{
Evaluasi Keberlanjutan Jembatan Timbang Di Jawa Barat
}

\author{
Ruktiningsih, R. ${ }^{1}$., Prakoso, H. ${ }^{2}$ \\ ${ }^{1}$ Program Studi Teknik Sipil, Fakultas Teknik, Universitas Soegijaparanata Semarang \\ rudatin.ruktiningsih@gmail.com \\ ${ }^{2}$ Badan Pengelola Transportasi Jabodetabek, Kementrian Perhubungan Republik Indonesia \\ hananto.prakoso@gmail.com
}

\begin{abstract}
Weighbridge station or UPPKB is land transportation facility which is used to measure vehicle weight and their load (Minister of Transportation Regulation no.134/2015). Weighbridge station is managed by Ministerial of Transportation, and has several function like supervision, taking measure, also record the flow of freight on highway in order to increase highway traffic safety. The problem is the effectiveness of most Indonesian weighbridge station which cannot perform their function properly. It can be proven by a lot of damage on Indonesian highway that could be caused by large (uncontrolled) amount of freight transport on the highway. The purpose of this study was to know about the present condition of weighbridge station in West Java, analyze its functions based on its location, and make recommendation for weighbridge station sustainability. The method we use is based on four steps transportation modelling which its consist of trip generation, trip distribution, modal split, and trip assignment also helped by Tranplan software to obtain evaluation criteria of each weighbridge or UPPKB. The result was 8 of weighbridge station in West Java must be operated.

Key words :Weighbridge station, freight transport, highway traffic safety
\end{abstract}

\begin{abstract}
Abstrak :Jembatan timbang atau UPPKB (Unit Pelaksana Penimbangan Kendaraan Bermotor) adalah prasarana transportasi darat yang berfungsi untuk mengukur berat kendaraan bermotor dan muatannya (Peraturan Menteri Perhubungan no. 134 tahun 2015). Instansi pengelola jembatan timbang adalah Kementerian Perhubungan. Fungsi jembatan timbang adalah untuk pengawasan, penindakan dan pencatatan arus angkutan barang yang melalui jalan raya dalam rangka peningkatan keselamatan lalu lintas jalan raya. Permasalahan yang terjadi adalah jembatan timbang yang ada di Indonesia selama ini kurang efektif dalam melakukan fungsinya, hal ini terbukti masih banyak jalan yang rusak yang kemungkinan disebabkan salah satunya adalah muatan berlebih. Tujuan penelitian ini adalah untuk mengetahui kondisi eksisting jembatan timbang yang ada di Jawa Barat, menganalisis fungsinya berdasarkan lokasi dan menyusun rekomendasi untuk keberlanjutan jembatan timbang tersebut. Metode yang dipergunakan untuk menganalisis adalah pemodelan transportasi yang berbasis four step models yaitu trip generation, trip distribution, modal split, serta trip assignment dan dibantu dengan software tranplan sehingga diperoleh kriteria evaluasi masing-masing jembatan timbang atau UPPKB. Hasil yang diperoleh menunjukkan bahwa dari 8 jembatan timbang yang ada di Jawa Barat harus dipertahankan untuk tetap dioperasikan.
\end{abstract}

Kata Kunci : Jembatan Timbang, Angkutan Barang, Keselamatan Lalu Lintas Jalan Raya 


\section{PENDAHULUAN}

Latar Belakang

Lalu lintas dipengaruhi oleh 4 faktor yaitu prasarana, sarana, user dan lingkungan. Keempat faktor tersebut saling berkolaborasi membentuk sistem lalu lintas. Prasarana adalah media yang mewadahi sarana dalam melakukan aktifitas pergerakan yaitu jalan raya, sarana adalah alat angkut, user adalah pengguna atau pelaku dan lingkungan adalah kondisi sekitar yang mempengaruhi pergerakan lalu lintas. Kolaborasi antara empat faktor tersebut dan perilakunya akan menyebabkan permasalahan lalu lintas antara lain kemacetan.

Kemacetan jalan raya sangat berpengaruh bagi pengguna lalu lintas terutama bagi angkutan barang, karena tujuan transportasi yaitu pemindahan barang, orang dan jasa dari suatu tempat ke tempat lain menjadi terhambat sehingga akan menimbulkan pemborosan terutama biaya dan waktu yaitu barang tidak dapat sampai ke tujuan dalam waktu yang tepat, terjadi pemborosan bahan bakar dan biaya operasional kendaraan yang berakibat semakin tingginya harga barang di tingkat konsumen.

Kondisi yang demikian disiasati oleh para pengusaha barang dengan cara membawa muatan yang melebihi kapasitas angkutan barang dengan maksud untuk menjaga harga barang di tingkat konsumsi. Hal ini berakibat angkutan barang menjadi overload yang menyebabkan permasalahan baru yaitu kerusakan prasarana jalan raya. Kondisi jalan raya yang rusak semakin menghambat kelancaran lalu lintas, sehingga semakin mahalnya biaya operasional angkutan barang. Hal demikian ibarat seperti lingkaran setan bagi angkutan barang.

Salah satu upaya pemerintah untuk mengatasi hal demikian adalah membangun sistem penimbangan barang di ruas-ruas jalan sebagai upaya memantau angkutan barang agar tidak membawa muatan berlebih. Perletakan prasarana penimbangan jalan sebagian besar berada di jalan nasional dan dikenal selama ini oleh masyarakat sebagai jembatan timbang.

Permasalahan jembatan timbang atau Unit Pelaksana Penimbangan Kendaraan Bermotor (UPPKB) adalah unit dibawah Kementerian Perhubungan Republik Indonesia yang bertugas mengawasi muatan barang yang dibawa oleh angkutan barang yang melintasi jalan dengan cara melakukan penimbangan (Peraturan Menteri Perhubungan RI no. 134 Tahun 2015).

Fungsi UPPKB adalah untuk melakukan pengawasan, pencatatan dan penindakan angkutan barang yang melintas sehingga kondisi prasarana jalan menjadi terjaga kualitasnya dan mampu menjamin keselamatan lalu lintas.

Di Jawa Barat terdapat 8 jembatan timbang atau UPPKB yang melakukan pengawasan angkutan barang di Jalan Nasional, namun kenyataan di lapangan, kondisi jalan-jalan tersebut tetap terjadi kerusakan sehingga kelancaran lalu lintas di ruas-ruas jalan tersebut masih terhambat. Hal ini mungkin disebabkan oleh beberapa aspek meliputi aspek teknis yaitu kondisi jembatan timbang dan aspek non teknis yaitu sumber daya manusia.

Permasalahan aspek teknis yang ditemui dilapangan adalah alat penimbangan yang tidak mampu mengikuti perkembangan alat angkut barang sehingga tidak semua angkutan barang mampu ditimbang, lokasi penimbangan yang tidak tepat atau tidak strategis, terlalu berdekatan, tidak dapat diakses dan luasan yang kurang adalah persoalan utama yang terjadi.

\section{Manfaat dan Tujuan Penelitian}

Manfaat yang hendak dicapai dalam penelitian ini adalah sebagai salah satu masukan bagi Kementerian Perhubungan dalam melakukan evaluasi keberadaan jembatan timbang atau UPPKB yang ada Jawa Barat terutama yang berlokasi di Jalan Nasional adalah dari aspek teknis 
yaitu lokasi dan keterjangkauan bagi angkutan barang.

Sedangkan tujuan penelitian ini adalah,

a. Mengetahui jembatan timbang atau UPPKB yang berada di jaringan lintas nasional di Jawa Barat

b. Mengetahu kondisi eksisting jembatan timbang atau UPPKB yang berada di jaringan lintas nasional di Jawa Barat

c. Mengetahui skenario keberlanjutan jembatan timbang atau UPPKB di jaringan lintas Nasional di Jawa Barat apakah ditutup atau tetap dioperasikan berdasarkan muatan, jarak dengan pusat logistik dan jumlah pusat logistik yang dilayani.

\section{Sistematika Penulisan}

Sistematika penulisan yang digunakan adalah sebagai berikut di bawah ini,

1. Pendahuluan, berisi tentang Latar Belakang, Formulasi Masalah, Manfaat dan Tujuan Penelitian, serta Sistematika Penulisan

2. Tinjauan Pustaka

3. Metode Penelitian

4. Hasil Penelitian dan Analisis

5. Kesimpulan dan Saran

Daftar Pustaka

\section{KAJIAN PUSTAKA \\ Transportasi}

Transportasi adalah pemindahan orang, barang atau jasa dari suatu tempat ke tempat lain (Salim,2002 dalam Ruktiningsih,2013), sehingga hal penting dalam transportasi adalah pergerakan (movement) dan perubahan tempat bagi muatan yang dipindahkan. Tujuan transportasi adalah melakukan pemindahan secara aman, nyaman, ekonomis , terjangkau dan dapat diandalkan. Transportasi berpengaruh sangat besar bagi perorangan, masyarakat, pembangunan ekonomi dan sosial ekonomi suatu masyarakat (Salim,2002 dalam Ruktiningsih,2013). Sedangkan kebutuhan transportasi dipengaruhi oleh pertumbuhan penduduk, pembangunan wilayah dan daerah, perdagangan, industrialisasi dan penyebaran penduduk (Salim, 2002 dalam Ruktiningsih,2013).

Faktor-faktor yang mempengaruhi transportasi adalah sarana, prasarana, pengguna (Khisty dan Lall,2006) namun faktor lingkungan juga ikut mempengaruhi ( Ruktiningsih , 2007 dalam Ruktiningsih, 2013). Empat faktor tersebut saling berkolaborasi, berinteraksi membentuk suatu sistem transportasi, secara skematik dapat dilihat pada Gambar 1 di bawah ini.

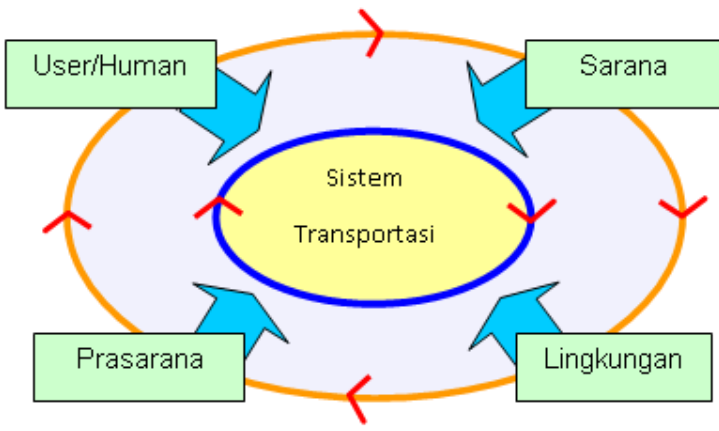

Gambar 1. Faktor-faktor Transportasi

(Sumber : Ruktiningsih,2007 dalam

Ruktiningsih,2013)

Sarana adalah alat transportasi atau moda transportasi yang digunakan sebagai alat pemindahan, sedangkan prasarana adalah media yang dilalui oleh sarana. User atau human adalah pelaku transportasi sedangkan lingkungan adalah kondisi atau keadaan yang berkaitan dengan kondisi sekitarnya. Interaksi keempat faktor tersebut akan membentuk sistem lalu lintas, dan apabila terjadi ketidak-seimbangan dari keempat faktor tersebut akan menimbulkan permasalahan. Permasalahan yang terjadi terutama di bidang transportasi darat adalah adalah pada angkutan barang dan angkutan penumpang karena masing-masing mempunyai karakteristik yang sangat berbeda.

\section{Angkutan Barang dan Kondisi Jalan}

Karakteristik angkutan barang dipengaruhi oleh jarak tempuh, volume dan berat yang sangat beragam sehingga mempunyai tuntutan atau persyaratan tersendiri dalam penyediaan sistem 
angkutannya (Kementerian Perhubungan, 2016). Menurut Warpani (1990:180), secara umum barang yang diangkut dikelompokkan menjadi,

a. Barang kering (dry bulk goods),

b. barang cair dan,

c. barangumum (general goods).

Setiap jenis barang akan mempengaruhi jenis moda transportasi yang akan dipakai sehingga setiap jenis barang akan mendapatkan penanganan yang tepat dari segi pengangkutan sehingga tujuan transportasi dapat tercapai. Menurut Ortuzar (1997: 390), beberapa faktor yang akan mempengaruhi pergerakan barang adalah,

a. lokasi, angkutan barang merupakan sebuah permintaan turunan yang menjadi bagian dari proses industri sehingga Lokasi sumber bahan mentah dan lokasi pemasaran produk menentukan tingkat pergerakan.

b. Faktor fisik, karakteristik komoditi bahan mentah dan produk sangat mempengaruhi cara pengangkutan dan jenis kendaraan.

c. Faktor operasional, akan menentukan saluran distribusi, sebaran geografis dan pilihan penggunaan moda transportasinya.

d. Faktor geografis, angkutan barang berfungsi menaklukan keadaan alam untuk memdekatkan lokasi produksi dengan kepadatan penduduk sebagai distribusi produk industri.

e. Faktor dinamik, perubahan permintaan dan selera konsumen memainkan peran penting pola pergerakan barang.

f. Faktor harga, angkutan barang memiliki kecenderungan lebih fleksibel dan masih memiliki kekuatan tawar menawar dalam penentuan harga angkutan.

Permasalahan yang sering terjadi adalah jumlah barang yang diangkut tidak sesuai dengan jalan yang dilalui sehingga berakibat jalan mudah rusak, sehingga pemerintah harus mengeluarkan anggaran untuk memperbaiki secara berulang-ulang. Hal ini salah satu penyebabnya adalah adanya toleransi beban berlebih sebesar 50 - $60 \%$ dari kekuatan jalan demikian pula menurut Kementrian PU dalam Bahri (2011) toleransi muatan yang diperkenankan adalah 50\%, sehingga kerusakan jalan 6,5\% kali lebih cepat ((Tamin dkk, 2008) dalam Wibawa,Fauzi dan Habibah,2013)). Mudah rusaknya jalan di Indonesia menyebabkan Biaya Operasional Kendaraan (BOK) Indonesia tinggi sehingga Indonesia berdasarkan penelitian Bank Dunia (2010) dalam Viva News (2011) menempati urutan 75 dari 150 negara dalam Global Indeks Kinerja Logistik (Wibawa, Fauzi dan Habibah,2013).Untuk mengatasi hal tersebut, pemerintah mengoperasikan jembatan timbang sebagai upaya mengendalikan muatan berlebih, sehingga kerusakan jalan akibat muatan berlebih dapat dikendalikan.

\section{Jembatan Timbang}

Jembatan Timbang atau UPPKB (Unit Pelaksana Penimbangan Kendaraan Bermotor) adalah unit di bawah Kementerian Perhubungan Republik Indonesia yang bertugas melakukan pengawasan, pencatatan dan penindakan bagi angkutan barang yang beroperasi di ruas jalan sebagai upaya untuk menjaga kondisi prasarana jalan raya dan keselamatan lalu lintas di jalan raya (Peraturan Menteri Perhubungan RI no. 134 Tahun 2015). Dan merupakan salah satu kebijakan pemerintah untuk melakukan perlindungan bagi jalan terhadap kerusakan akibat muatan berlebih dan keselamatan lalu lintas (W. Seno, dkk,2014). Fungsi tersebut meliputi tata cara pemuatan,jenis yang diangkut, tujuan, berat barang, jenis, dimensi dan tipe kendaraan serta kelaikan kendaraan.

Jenis kendaraan yang dilakukan penimbangan adalah semua angkutan 
barang kecuali angkutan kontainer, tangki BBM dan BBG, angkutan barang berbahaya dan angkutan alat berat.

Pemasangan jembatan timbang atau UPPKB dilakukan di ruas jalan nasional dan ruas jalan strategis nasional seperti kawasan industri, sentra produksi, pelabuhan, jalan tol dan kawasan strategis lainnya.

UPPKB dibedakan dalam 2 tipe berdasarkan jumlah kendaraan yang melalui ruas jalan lokasi UPPKB atau jembatan timbang berada tiap hari yaitu,

a. Tipe I yaitu jembatan timbang atau UPPKB yang terletak pada ruas jalan dengan jumlah angkutan barang lebih kecil dari 2000 kendaraan per-arah perhari sehingga membutuhkan satu platform alat timbang

b. Tipe II yaitu jembatan timbang atau UPPKB yang berada di ruas jalan dengan jumlah angkutan barang minimal 2000 kendaraan per-arah perhari sehingga membutuhkan lebih dari satu platform alat penimbang.

Jenis platform alat penimbang mempunyai persyaratan tertentu yaitu,

a. Mampu menimbang minimal 80 ton

b. Panjang platform alat penimbang minimal 18 meter

c. Memakai Satuan Sistem Internasional (SI)

d. Mempunyai sistem elektronik digital.

Saat ini jembatan timbang yang ada tidak efektif dalam upaya menjaga jalan dari kerusakan karena adanya toleransi muatan berlebih melalui jembatan timbang (Atiya, 2014).

\section{METODOLOGI PENELITIAN}

Lokasi penelitian adalah pada jembatan timbang atau UPPKB yang berada di Jawa Barat dengan cara melakukan pendataan awal lokasi, karakteristik dan kondisi eksisting jembatan timbang atau UPPKB dan kondisi angkutan barang yang melintasi lokasi tersebut.

Berdasarkan data tersebut kemudian dilakukan pemodelan transportasi. Pemodelan yang digunakan adalah model perencanaan transportasi empat tahap yaitu model transportasi yang berbasis pada Trip Generation, Trip Distribution, Modal Split dan Trip Assignment serta dibantu dengan Software simulasi makro TRANPLAN (Transport Planning) yaituprogram analisis jaringan yang dikembangkan oleh Urban Analysis Group sejak tahun 1990. Kalibrasi model dilakukan dengan menggunakan data kondisi jaringan transportasi (jalan) serta pola tata ruang eksisting di kawasan stud dan forecasting sampai dengan 2025. Dari hasil kalibrasi diperoleh beberapa model yang diperlukan untuk prediksi permintaan perjalanan dan kinerja sistem transportasi di masa datang. Prediksi pola tata ruang di masa datang dilakukan dengan menggunakan data rencana pengembangan kawasan serta tinjauan terhadap tata ruang wilayah yang diperoleh dari dokumen yang ada serta wawancara dengan pihak terkait.

Dari hasil prediksi permintaan perjalanan, tingkat pelayanan dan juga mempertimbangkan pola tata ruang wilayah eksisting dan masa datang, maka dapat dilakukan proses analisis dan optimalisasi unit pelaksana penimbangan kendaraan bermotor eksisting. Dari model optimasi yang dibangun, akan terlihat apakah lokasi unit pelaksana penimbangan kendaraan bermotor saat ini sudah ideal atau diperlukan pengembangan baru. Identifikasi dan estimasi kebutuhan UPPKB, meliputi:

a. Analisis lokasi dan kebutuhan pengembangan UPPKB;

b. Analisis jaringan lintas angkutan barang;

Secara sistematik metode analisis dapat dilihat pada Gambar 2. 
HASIL PENELITIAN DAN ANALISIS

Berdasarkan hasil survey diperoleh data bahwa Jawa Barat dengan jumlah penduduk sebesar 47.048.991 orang (BPS RI,2016) ,jumlah angkutan barang 817.732 buah (Ditjendat RI,2016), panjang jalan Nasional tercatat di Kementerian PU berdasarkan KM PU PERA No.248/KPTS/M/2015 sepanjang 1789,20 $\mathrm{km}$. Sedangkan jumlah simpul-simpul logistik yang ada di Jawa Barat sebagai bangkitan atau tarikan angkutan barang tercatat sebanyak 23 kawasan industri (Himpunan Kawasan Industri Indonesia,2015) dan menduduki peringkat pertama terbanyak jumlah kawasan industri. dan 1 pelabuhan laut, adapun jumlah jembatan timbang atau UPPKB yang ada di Jawa Barat, ditampilkan dalam Tabel 1.

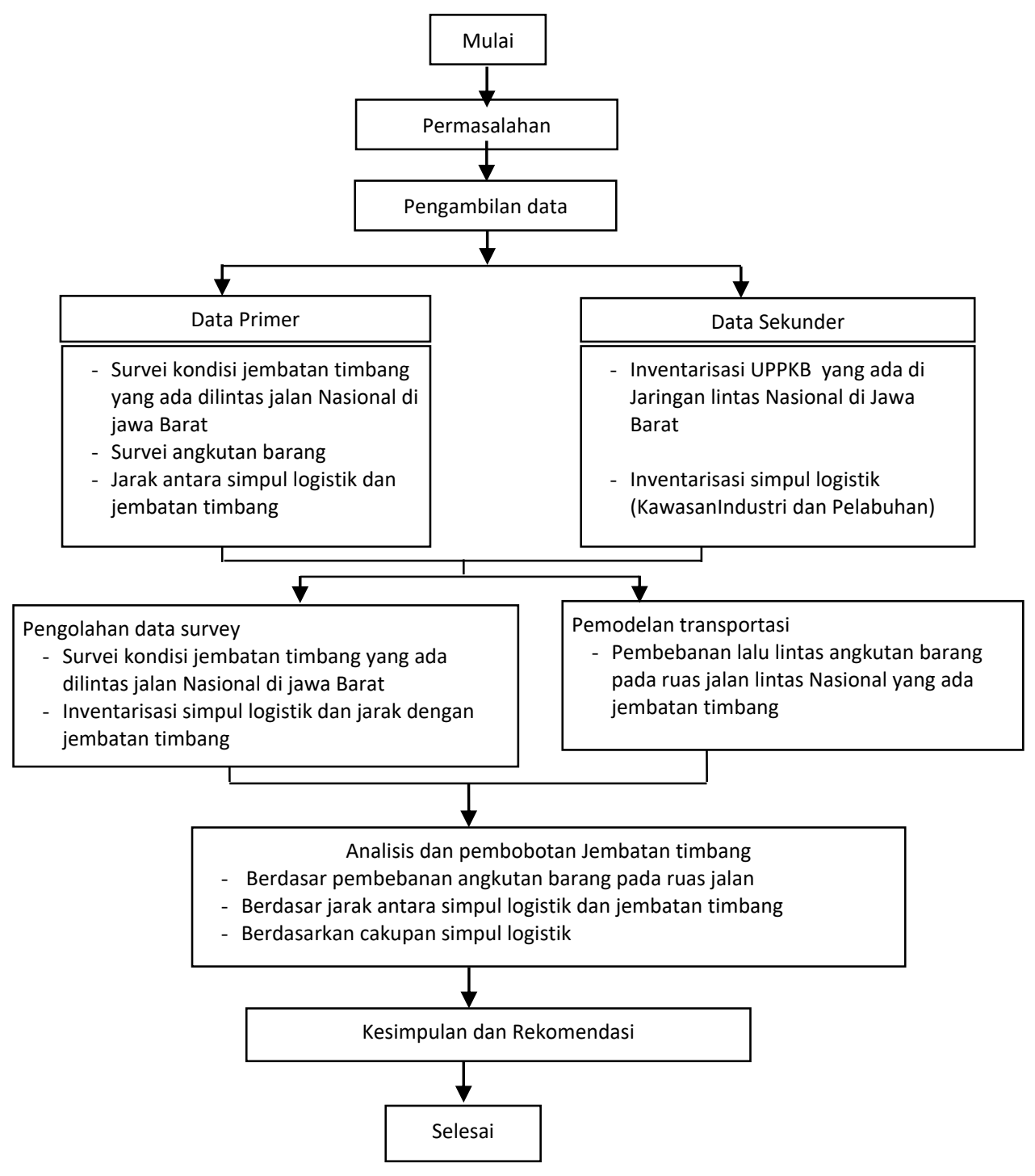

Gambar 2 Bagan alir penelitian

Tabel 1.Inventarisasi UPPKB eksistingdi Jawa Barat

\begin{tabular}{llccl}
\hline No & NamaUPPKB & Arah Pelayanan & Keterangan & Provinsi \\
\hline 1 & UPPKB Balonggandu & 1 & Beroperasi & \\
2 & UPPKB Losarang & 1 & Beroperasi & Jawa Barat \\
3 & UPPKB Cibaragalan & 1 & Beroperasi &
\end{tabular}




\begin{tabular}{|c|c|c|c|c|}
\hline No & NamaUPPKB & Arah Pelayanan & Keterangan & Provinsi \\
\hline 4 & UPPKB Sindang Rasa & 2 & Beroperasi & \\
\hline 5 & UPPKB Bojong & 1 & Beroperasi & \\
\hline 6 & UPPKB Kemang & 2 & Beroperasi & \\
\hline 7 & UPPKB Tomo & 2 & Beroperasi & \\
\hline 8 & UPPKB Gentong & 2 & Beroperasi & \\
\hline
\end{tabular}

(Sumber : Ditjendat,2016)

Berdasarkan tabel di atas dapat dilihat bahwa pelayanan jembatan timbang Balonggandu, Losarang, Cibaragalan dan Bojong hanya 1 arah artinya ruas jalan yang melalui jembatan timbang tersebut adalah satu arah. Sedangkan jembatan timbang Sindang Rasa, Kemang, Tomo dan Gentong melayani angkutan barang dalam dua arah artinya ruas jalan yang melalui jembatan timbang tersebut tanpa pemisah arah. Seluruh jembatan timbang sampai saat ini kondisinya aktif beroperasi.

Berdasarkan data survey angkutan barang yang ada dan dilakukan forecasting hingga tahun 2025, disusun kriteria untuk melakukan penilaian atau evaluasi masingmasing jembatan timbang berdasarkan beban muatan angkutan barang, jarak antara simpul logistik dan jumlah simpul logistik.

Kriteria evaluasi tersebut adalah kriteria pembobotan yaitu dikategorikan menjadi 3 jenis yaitu tinggi, sedang, dan rendah. Untuk kriteria tinggi memiliki bobot 3, untuk kriteria sedang memiliki bobot 2, dan untuk kriteria rendah memiliki bobot 1. Dan untuk jenis indikator yang digunakan sebagai dasar pembobotan yaitu :

a) Beban muatan angkutan barang dari hasil survei/model pembebanan (ton/hari) yaitu rendah apabila muatan yang membebani ruas jalan tersebut lebih kecil dari 15000 ton/hari, sedang antara 15000 sampai dengan 25000 ton/hari dan tinggi apabila lebih besar dari 25000 ton/hari.

b) Kedekatan UPPKB dengan simpul seperti pelabuhan dan kawasan industri $(\mathrm{km})$; untuk kategori tinggi yaitu dengan jarak rata-rata $<40 \mathrm{~km}$, kategori sedang dengan jarak rata-rata 40-80 Km, dan kategori rendah dengan jarak rata-rata lebih dari 80 $\mathrm{Km}$; dan

c) Jumlah simpul pelabuhan dan kawasan industri untuk kategori rendah $<3$ Simpul, kategori sedang 35 simpul, dan kategori tinggi $>5$ simpul.

Nilai rata-rata kriteria keputusan yang telah dibobotkan menjadi acuan untuk menentukan apakah UPPKB dapat dipertahankan atau ditutup operasinya. Kriteria UPPKB dapat ditutup apabila nilai rata-rata pembobotan kurang dari 1,5, sedangkan jika nilai rata-rata pembobotan lebih besar atau samadengan 1,5 maka status UPPKB dapat dipertahankan, dioperasikan kembali atau dibangun baru.

Berdasarkan kriteria di atas diperoleh hasil evaluasi jembatan timbang atau UPPKB di Jawa Barat yang ditampilkan dalam Tabel 2 di bawah ini,

Tabel 2. Evaluasi Jembatan Timbang atau UPPKB berdasarkan pergerakan angkutan barang

\begin{tabular}{|c|c|c|c|c|c|c|c|}
\hline $\begin{array}{c}\text { Nama } \\
\text { Jembatan } \\
\text { Timbang/UP } \\
\text { PKB }\end{array}$ & $\begin{array}{c}\text { Klasifikasi } \\
\text { Pembebanan } \\
\text { Link }\end{array}$ & $\begin{array}{c}\text { Arah } \\
\text { Pelaya } \\
\text { nan }\end{array}$ & $\begin{array}{c}\text { Kondisi } \\
\text { Eksisting }\end{array}$ & $\begin{array}{c}\text { Justifikasi } 1 \\
\text { (Pola Perjalanan) }\end{array}$ & $\begin{array}{c}\text { Justifikasi 2 } \\
\text { (Potensi } \\
\text { pelabuhan/Kawasan } \\
\text { Industri) }\end{array}$ & $\begin{array}{c}\text { Justifikasi } \\
3 \text { (Kondisi } \\
\text { Median) }\end{array}$ & Evaluasi \\
\hline Balonggandu & Tinggi & 1 & Beroperasi & $\begin{array}{l}\text { Potensi Perjalanan dari } \\
\text { Provinsi Jawa Barat } \\
\text { menuju DKI }\end{array}$ & $\begin{array}{l}\text { 1. Potensi Angkutan } \\
\text { Barang dari Jawa Barat } \\
\text { menuju Pelabuhan } \mathrm{Tj} \text {. } \\
\text { Priok }(76,48 \mathrm{~km})\end{array}$ & Ada & $\begin{array}{l}\text { Dipertahanka } \\
\mathrm{n} \text { dengan } 1 \\
\text { Arah }\end{array}$ \\
\hline
\end{tabular}




\begin{tabular}{|c|c|c|c|c|c|c|c|}
\hline $\begin{array}{c}\text { Nama } \\
\text { Jembatan } \\
\text { Timbang/UP } \\
\text { PKB } \\
\end{array}$ & $\begin{array}{c}\text { Klasifikasi } \\
\text { Pembebanan } \\
\text { Link }\end{array}$ & $\begin{array}{c}\text { Arah } \\
\text { Pelaya } \\
\text { nan }\end{array}$ & $\begin{array}{l}\text { Kondisi } \\
\text { Eksisting }\end{array}$ & $\begin{array}{c}\text { Justifikasi } 1 \\
\text { (Pola Perjalanan) }\end{array}$ & $\begin{array}{c}\text { Justifikasi 2 } \\
\text { (Potensi } \\
\text { pelabuhan/Kawasan } \\
\text { Industri) } \\
\end{array}$ & $\begin{array}{c}\text { Justifikasi } \\
3 \text { (Kondisi } \\
\text { Median) }\end{array}$ & Evaluasi \\
\hline Losarang & Tinggi & 1 & Beroperasi & $\begin{array}{l}\text { Potensi Perjalanan dari } \\
\text { DKI menuju Provinsi } \\
\text { Jawa Barat }\end{array}$ & $\begin{array}{l}\text { 2. Potensi Kawasan } \\
\text { Industri dari Jawa } \\
\text { Barat menuju Bekasi - } \\
\text { Karawang } \\
\text { 1. Potensi Angkutan } \\
\text { Barang dari } \\
\text { Pelabuhan Tj. Priok } \\
\text { menuju Jawa Barat } \\
\text { (142,65 km) } \\
\text { 2. Potensi Kawasan } \\
\text { Industri Bekasi - } \\
\text { menuju Jawa Barat } \\
\text { 3. Potensi Angkutan } \\
\text { Barang dari Wilayah } \\
\text { Jabar Bagian Barat } \\
\text { menuju Pelabuhan } \\
\text { Cirebon (60,19 km) }\end{array}$ & Ada & $\begin{array}{l}\text { Dipertahanka } \\
\mathrm{n} \text { dengan } 1 \\
\text { Arah }\end{array}$ \\
\hline Cibaragalan & Sedang & 1 & Beroperasi & $\begin{array}{l}\text { Potensi Perjalanan dari } \\
\text { Bandung menuju } \\
\text { DKI/Pantura }\end{array}$ & $\begin{array}{l}\text { Potensi Kawasan } \\
\text { Industri Lion, } \\
\text { Purwakarta menuju } \\
\text { DKI/Pantura }(5,85 \mathrm{~km})\end{array}$ & Tidak Ada & $\begin{array}{l}\text { Diperta } \\
\text { hankan } \\
\text { dengan } 1 \\
\text { Arah }\end{array}$ \\
\hline Sindang Rasa & Tinggi & 2 & Beroperasi & $\begin{array}{l}\text { Potensi Perjalanan } \\
\text { Arus Keluar Masuk } \\
\text { Jabar-Jateng Bagian } \\
\text { Selatan (lokasi } \\
\text { Wilayah Barat) }\end{array}$ & $\begin{array}{l}\text { Potensi Angkutan } \\
\text { Barang dari Jabar Bagian } \\
\text { Selatan dan menuju } \\
\text { Pelabuhan Tanjung Intan } \\
(131,35 \mathrm{~km})\end{array}$ & Tidak Ada & $\begin{array}{l}\text { Diperta } \\
\text { hankan } \\
\text { dengan } 2 \\
\text { Arah }\end{array}$ \\
\hline Bojong & Tinggi & 1 & Beroperasi & $\begin{array}{l}\text { Potensi Perjalanan } \\
\text { Arus dari DKI dan } \\
\text { Sukabumi menuju } \\
\text { Jabar Bagian Tengah }\end{array}$ & $\begin{array}{l}\text { 1. Potensi Angkutan } \\
\text { Barang Dari Pel. Ratu } \\
\text { menuju Jabar Bagian } \\
\text { Tengah/Selatan } \\
\text { 2. Potensi Kawasan } \\
\text { Industri Cikarang, } \\
\text { menuju Kawasan } \\
\text { Rancaekek }(81,86 \mathrm{~km})\end{array}$ & Tidak Ada & $\begin{array}{l}\text { Diperta } \\
\text { hankan } \\
\text { dengan } 1 \\
\text { Arah }\end{array}$ \\
\hline Kemang & Tinggi & 2 & Beroperasi & $\begin{array}{l}\text { Potensi Perjalanan } \\
\text { Arus Keluar Masuk } \\
\text { Tangsel Batas Jabar- } \\
\text { Banten/DKI }\end{array}$ & $\begin{array}{l}\text { Potensi Kawasan } \\
\text { Industri Cibinong-Sentul } \\
(6,75 \mathrm{~km})\end{array}$ & Tidak Ada & $\begin{array}{l}\text { Diperta } \\
\text { hankan } \\
\text { dengan } 2 \\
\text { Arah }\end{array}$ \\
\hline Tomo & Tinggi & 2 & Beroperasi & $\begin{array}{l}\text { Potensi Perjalanan } \\
\text { Arus Keluar Masuk } \\
\text { dari } \\
\text { Bandung/Tasikmalaya } \\
\text {-Kadipaten }\end{array}$ & $\begin{array}{l}\text { Potensi Arus Keluar } \\
\text { Masuk Angkutan Barang } \\
\text { dari Jabar Bagian } \\
\text { Selatan menuju Kawasan } \\
\text { Industri Rancaekek } \\
(60,83 \mathrm{~km})\end{array}$ & Tidak Ada & $\begin{array}{l}\text { Diperta } \\
\text { hankan } \\
\text { dengan } 2 \\
\text { Arah }\end{array}$ \\
\hline Gentong & Tinggi & 2 & Beroperasi & $\begin{array}{l}\text { Potensi Perjalanan } \\
\text { Arus Keluar Masuk } \\
\text { dari Bandung-Jabar } \\
\text { Bagian Selatan menuju } \\
\text { Jawa Tengah }\end{array}$ & $\begin{array}{l}\text { Potensi Arus Keluar } \\
\text { Masuk Angkutan Barang } \\
\text { dari Jabar Bagian } \\
\text { Selatan menuju Kawasan } \\
\text { Industri Rancaekek } \\
(48,21 \mathrm{~km}) \\
\end{array}$ & Tidak Ada & $\begin{array}{l}\text { Diperta } \\
\text { hankan } \\
\text { dengan } 2 \\
\text { Arah }\end{array}$ \\
\hline
\end{tabular}

(Sumber :Hasil survey yang dianalisis,2016)

Tabel 3. Hasil Evaluasi Jembatan Timbang atau UPPKB

\begin{tabular}{|c|c|c|c|c|c|c|c|c|c|c|c|c|}
\hline \multirow{3}{*}{$\begin{array}{c}\text { Nama } \\
\text { UPPKB }\end{array}$} & \multirow{3}{*}{$\begin{array}{c}\text { Kondisi } \\
\text { Eksisting }\end{array}$} & \multicolumn{11}{|c|}{ Indikator Penilaian } \\
\hline & & \multicolumn{2}{|c|}{ Beban Ruas Jalan } & \multirow[b]{2}{*}{ Bobot } & \multicolumn{2}{|c|}{$\begin{array}{c}\text { Kedekatan } \\
\text { Simpul }\end{array}$} & \multirow[b]{2}{*}{ Bobot } & \multicolumn{2}{|c|}{ Cakupan Simpul } & \multirow[b]{2}{*}{ Bobot } & \multirow[b]{2}{*}{$\begin{array}{l}\text { Bobot } \\
\text { Rata- } \\
\text { Rata }\end{array}$} & \multirow[b]{2}{*}{$\begin{array}{c}\text { Hasil } \\
\text { Penilaian }\end{array}$} \\
\hline & & Ton/hari & Kategori & & $\begin{array}{c}\text { Jarak } \\
\text { rata- } \\
\text { rata } \\
(\mathbf{k m}) \\
\end{array}$ & Kategori & & Jumlah & Kategori & & & \\
\hline Balonggandu & Operasi & 15000 & Sedang & 1 & 17,99 & Tinggi & 3 & 6 & Tinggi & 3 & 2,33 & Dipertahankan \\
\hline Losarang & Operasi & $>25000$ & Tinggi & 3 & 71,75 & Rendah & 1 & 2 & Rendah & 1 & 1,67 & Dipertahankan \\
\hline Cibaragalan & Operasi & $\begin{array}{l}15000- \\
25000\end{array}$ & Sedang & 2 & 12,05 & Tinggi & 3 & 4 & Sedang & 2 & 2,33 & Dipertahankan \\
\hline $\begin{array}{l}\text { Sindang } \\
\text { Rasa }\end{array}$ & Operasi & $>25000$ & Tinggi & 3 & 70,61 & Rendah & 1 & 1 & Rendah & 1 & 1,67 & Dipertahankan \\
\hline
\end{tabular}




\begin{tabular}{|c|c|c|c|c|c|c|c|c|c|c|c|c|}
\hline \multirow{3}{*}{$\begin{array}{c}\text { Nama } \\
\text { UPPKB }\end{array}$} & \multirow{3}{*}{$\begin{array}{l}\text { Kondisi } \\
\text { Eksisting }\end{array}$} & \multicolumn{11}{|c|}{ Indikator Penilaian } \\
\hline & & \multicolumn{2}{|c|}{ Beban Ruas Jalan } & \multirow[b]{2}{*}{ Bobot } & \multicolumn{2}{|c|}{$\begin{array}{c}\text { Kedekatan } \\
\text { Simpul }\end{array}$} & \multirow[b]{2}{*}{ Bobot } & \multicolumn{2}{|c|}{ Cakupan Simpul } & \multirow[b]{2}{*}{ Bobot } & \multirow[b]{2}{*}{$\begin{array}{l}\text { Bobot } \\
\text { Rata- } \\
\text { Rata }\end{array}$} & \multirow[b]{2}{*}{$\begin{array}{c}\text { Hasil } \\
\text { Penilaian }\end{array}$} \\
\hline & & Ton/hari & Kategori & & $\begin{array}{c}\text { Jarak } \\
\text { rata- } \\
\text { rata } \\
(\mathbf{k m})\end{array}$ & Kategori & & Jumlah & Kategori & & & \\
\hline Bojong & Operasi & $>25000$ & Tinggi & 3 & 200,00 & Rendah & 1 & 1 & Rendah & 1 & 1,67 & Dipertahankan \\
\hline Kemang & Operasi & $>25000$ & Tinggi & 3 & 13,79 & Tinggi & 3 & 1 & Rendah & 1 & 2,33 & Dipertahankan \\
\hline Tomo & Operasi & $>25000$ & Tinggi & 3 & 45,89 & Sedang & 2 & 2 & Rendah & 1 & 2,00 & Dipertahankan \\
\hline Gentong & Operasi & $>25000$ & Tinggi & 3 & 41,12 & Sedang & 2 & 1 & Rendah & 1 & 2,00 & Dipertahankan \\
\hline
\end{tabular}

Hasil analisis terhadap muatan yang membebani ruas jalan terlihat bahwa jembatan timbang Losarang, Sindang Rasa, Bojong, Kemang, Tomo dan Gentong mempunyai kategori tinggi karena dilewati angkutan barang dengan muatan lebih besar dari 25000 ton/hari. Hal ini mengindikasikan bahwa ruas jalan tersebut padat dilewati angkutan barang atau angkutan barang yang melalui ruas jalan tersebut bermuatan tinggi. Sedangkan untuk jembatan timbang Balonggandu dan Cibaragalan beban ruas jalan adalah $15.000-25.000$ ton/hari artinya tonase yang melalui ruas jalan tersebut lebih rendah dari keenam jembatan timbang sebelumnya.

Ditinjau dari kedekatan antara jembatan timbang dan simpul-simpul bangkitan angkutan barang seperti kawasan industri, pelabuhan, diperoleh hasil Jembatan timbang Balonggandu dan Kemang berada dekat dengan pusat-pusat bangkitan angkutan barang artinya keberadaan jembatan timbang sangat diperlukan untuk mengontrol muatan yang keluar dari pusatpusat bangkitan angkutan barang agar tidak membebani jalan raya.

Berdasarkan jumlah simpul yang dapat dilayani oleh jembatan timbang, ternyata Balonggandu menangkap pergerakan angkutan barang paling banyak karena berasal dari 6 titik simpul bangkitan angkutan barang artinya strategis dalam pengawasan pergerakan angkutan barang, disusul oleh Cibaragalan yang menangkap pergeraan dari 4 simpul bangkitan angkutan barang.
Hasil analisis keseluruhan berdasarkan ketiga kriteria menunjukkan bahwa bobot rata-rata tertinggi adalah jembatan Ballonggandu, Cibaragalan dan Kemang yaitu 2,33, kemudian disusul Tomo dan Gentong sebesar 2,0 kemudian Losarang, Sindang Rasa dan Bojong sebesar 1,67. Berdasarkan kriteria-kriteria yang ada adalah 8 jembatan timbang lebih dari 1,5 artinya 8 jembatan timbang atau UPPKB di Jawa Barat tetap dipertahankan untuk dioperasikan sebagai upaya pengawasan, pencatatan dan penindakan bagi angkutan barang yang beroperasi di ruas jalan untuk menjaga kondisi prasarana jalan raya dan keselamatan lalu lintas di jalan raya.

\section{SIMPULAN}

Berdasarkan analisis dan pembahasan, maka kesimpulan yang diperoleh adalah sebagai berikut,

1. Jawa Barat mempunyai 8 jembatan timbang yang berada di ruas jalan nasional

2. Kondisi eksisting saat ini 8 jembatan timbang tersebut aktif beroperasi

3. Berdasarkan analisis pembebanan jalan raya karena muatan yang melalui tiap hari terlihat bahwa jembatan timbang Losarang, Sindang Rasa, Bojong, Kemang, Tomo dan Gentong mempunyai kategori tinggi karena dilewati angkutan barang dengan muatan lebih besar dari 25000 ton/hari.

4. Berdasarkan jarak dengan pusat bangkitan angkutan barang diperoleh hasil Jembatan timbang Balonggandu dan Kemang berada paling dekat 
dengan pusat-pusat bangkitan angkutan barang.

5. Berdasarkan jumlah simpul yang dapat dilayani oleh jembatan timbang, ternyata Balonggandu menangkap pergerakan angkutan barang paling banyak karena berasal dari 6 titik simpul bangkitan angkutan barang.

6. Hasil analisis keseluruhan berdasarkan ketiga kriteria yaitu pembebanan jalan raya, jarak dengan simpul bangkitan angkutan barang dan jumlah simpul bangkitan yang dilayani menunjukkan bahwa bobot rata-rata tertinggi adalah jembatan Ballonggandu, Cibaragalan dan Kemang yaitu 2,33, Tomo dan Gentong sebesar 2,0 kemudian Losarang, Sindang Rasa dan Bojong sebesar 1,67.

7. Berdasarkan kriteria-kriteria yang ada 8 jembatan timbang mempunyai bobot rata-rata lebih dari 1,5 artinya 8 jembatan timbang atau UPPKB di Jawa Barat tetap dipertahankan untuk dioperasikan

\section{DAFTAR PUSTAKA}

1. Atiya Arief Fath dkk, Analisis Pengaruh Kinerja Jembatan Timbang terhadap Kinerja Perkerasan dan Umur Rencana Jalan, Jurnal Karya Teknik Sipil Vol. 3 No.3, Jurnal Online Universitas Diponegoro, Semarang, 2014

2. Badan Pusat Statistik RI, Indonesia dalam Angka, BPS RI, Jakarta, 2016.

3. Bahri Samsul, Identifikasi Jenis dan Berat Kendaraan melalui Jembatan Timbang, Jurnal Inersia Vol.2 No.2 ISSN: 2086 9045, Fakultas Teknik
Universitas Bengkulu, Bengkulu, 2011

4. Kementrian PUPR RI, Panjang Jalan Nasional, Keputusan Menteri Pekerjaan Umum dan Perumahan Rakyat No.248/KPTS/M/2015, Kementerian Pekerjaan Umum dan Perumahan Rakyat, Jakarta, 2015.

5. Kentrian Perhubungan RI, Penimbangan Kendaraan Bermotor di Jalan, Peraturan Menteri Perhubungan Republik Indonesia No. 134 Tahun 2015, Kementerian Perhubungan RI, Jakarta, 2015.

6. P.T. Scalarindo Jakarta, Penyusunan Rencana Induk Unit Pelaksana Penimbangan Kendaraan Bermotor (UPPKB) Indonesia, Dokumen Studi, Direktorat Prasarana Kenterian Perhubungan Republik Indonesia, Jakarta, 2016.

7. Ruktiningsih, R., Kajian Kebutuhan Taksi Kota Semarang, Dinas Perhubungan Komunikasi dan Informatika Kota Semarang, Laporan Penelitian, Semarang, 2013.

8. Wibawa,Fauzi, Habibah, Efektifitas Pengawasan Pungutan Liar di Jembatan Timbang, Jurnal Administrasi Negara Vol.12 No.2 Januari, Fakultas Ilmu Sosial dan Politik UGM, Yogyakarta, 2013.

9. W. Seno Ananto Nicolas, dkk, Analisis Antrian Angkutan Barang pada Jembatan Timbang dengan Metode Simulasi Multiple Channel (Studi Kasus pada Jembatan Timbang Sarang), Jurnal Karya Teknik Sipil Vol.3 No.4, Jurnal Online Universitas Diponegoro Semarang, 2014. 